\title{
Democratic Decentralization and Participatory Development: Focus on Bangladesh
}

\author{
Pronita Dutta*) \\ Department of Public Administration, Faculty of Social Science, Bangabandhu Sheikh \\ Mujibur Rahman Science and Technology University, Gopalganj-8100, The People's Republic \\ of Bangladesh.
}

Received: 2020-06-23; Accepted: 2020-09-22; Published: 2020-10-27

\begin{abstract}
In recent decades, developing Asian nations have witnessed the emergence of democratic decentralized governance structures, and with it a shift towards a more people-centric approach to development. Proponents claim the new approach can humanize bureaucracies and provide solutions to problems of poverty and social inequity. Despite their popularity, difficulties in implementation have been found, and questions are now being asked about the 'real' effectiveness of such frameworks. Discussing first the tenets of participatory development and its symbiotic relationship with democratic decentralized on this paper looks at the challenges faced in decentralizing a decentralized participatory framework and the critical components needed for success. It draws on examples from within developing Asia to highlight the many complexities of the issue, such as different cultural beliefs, political forces, administrative arrangements and varying perceptions. It argues that where incorrectly implemented, a decentralized participatory structure can prove ineffective for local people, in some cases leading to practical disillusions and further disadvantage.
\end{abstract}

Keywords: Democratic Decentralization; Participation; Development; Asia; Bangladesh

How to Cite: Dutta, P. (2020). Democratic Decentralization and Participatory Development: Focus on Bangladesh. Journal of Contemporary Governance and Public Policy, 1(2), 82-91.

Permalink/D0I: https://doi.org/10.46507/jcgpp.v1i2.23 


\section{Introduction}

The

globalization

emergence of and democratic governance structures experienced by many developing countries in the 1980s, brought about a move towards the adoption of many decentralized development ideologies and governance practices (H. Zafarullah \& Huque, 2012). Democratic decentralization or the devolution of powers to local levels has been embraced as an alternative governance structure, with the expectation that it would facilitate heightened transparency and accountability (Guess, 2005), increase responsive and innovative services, and foster more democratic, accountable and equitable management plans (Abbass, 2004). It came at a time when the expanding global community began realizing that economic and social benefits attached to previous development initiatives were being unfairly apportioned among the local people (Rondinelli, Nellis, \& Cheema, 1983). As a solution to this, the concepts of political socialization and civic participation were proposed (H. M. Zafarullah \& Huque, 2006).

This paper will review the tenets of participatory development and its symbiotic relationship with democratic decentralization. It considers the challenges experienced in implementation and the critical components needed for its effectiveness in reducing poverty and increasing social rights among local people. It draws on examples from within developing Asia, especially Bangladesh, showing that, where incorrectly implemented, a decentralized participatory structure can be ineffective for local development and people's welfare and, in some instances, leading to practical failures and further deprivations (Balooni \& Inoue, 2007;
Nagel, Heidhues, Horne, \& Neef, 2004).

\section{Research Methods}

This article draws from the conceptual and empirical literature on decentralization and participatory development and seeks to find a link between the two. It applies a broad exploratory-interpretive analysis of developments and experiences from an Asian perspective. The sources for this short study are books, book chapters, journal articles, reports and online materials.

\section{Conceptual Issues}

The idea of decentralization is premised on people's participation and equal access to opportunities at the ground level. It bolsters democratic representativeness, strengthens governmental accountability and reinforces public service effectiveness. It has the potential to "improve the political involvement of the people in public decision-making..., strengthen democracy and spur [a] country's development efforts" (Muño, Acosta, \& Moreno, 2006). Democratic decentralization focus on dispersing power and authority from central to local levels of the state. Civic participation gives decentralization the drive to work effectively within a democratic milieu. In fact, the symbiotic relationship between democratic decentralized governance and civic participation is commonly recognized (H. M. Zafarullah, 2004). Many believe that democratic decentralization is fruitless, or indeed a fallacy, without civic participation, whilst the latter is considered difficult to facilitate within a centralized governance framework (Lane, 1995; H. M. Zafarullah, 2004; H. M. Zafarullah \& Huque, 2006). Participation and delegation of controls to local people in all stages of the development process is the 
essence on which a community's democratic development culture is built. Participations' mutually beneficial relationship with decentralized governance is evident through its potential to reinforce civic capacity and raise the quality of democracy by enforcing bureaucratic accountability, promoting transparency, inducing higher levels of State interest in local needs and reducing the risk of authoritative implacableness, misconduct and corruption (Lane, 1995; H. M. Zafarullah, 2004; H. M. Zafarullah \& Huque, 2006). participatory development is about "involving local people and engaging and empowering the poor to take control of their own development" (Thomas, 2013). It is a pre-determined manipulative tool engaging people in a range of development activities through a well-designed process (Keough, 1998). There is a distinction between participation and participatory development. Participation is about being involved in an activity either nominally, passively or actively (Agarwal, 2001). Enabling someone to be a participant makes participation an end in itself, whereas participator development is both an end and a means being a process (Mohan, 2007; Parfitt, 2004).

\section{States}

approach

decentralization from an either political, administrative, fiscal or economic perspective or by a combination of these (H. M. Zafarullah, 2004). Moreover, depending on the extent to which centralized governments are willing to relinquish or share power, decentralization can take the form of deconcentration, delegation, devolution or privatization (Rondinelli \& Nellis, 1986; H. M. Zafarullah, 2004). Both deconcentration and delegation represent more tightly controlled approaches whereby power and authority stay within government but responsibility and some discretion, typically around administrative functions only, is given to local governments or agencies. Devolution provides greater freedom and gives some political controls to local autonomous units, including local people. Conversely, privatization provides more freedom again, whereby the control and implementation of initiatives are managed by NGOs or private sectors without the intervention of government (H. M. Zafarullah, 2004). Chambers (2013) argues that "participation has implications for power relations, personal interactions, and attitudes and behaviours..."

\section{Civic participation}

The notion of civic participation has become a key paradigm in modern thinking among both governmental/intergovernmental agencies and nongovernmental organizations (NGOs), particularly in how it relates to democratic decentralization (Hussein, 1995; H. Zafarullah \& Huque, 2012). As governments have begun to recognize the criticality in involving people at the grassroots in development implementation and planning, participatory practices have gradually replaced 'top-down' governance techniques $(H)$.$M .$ Zafarullah, 2004) and become an almost essential prerequisite for the democratic decentralized governance of development projects (Agarwal, 2001; H. M. Zafarullah \& Huque, 2006). Its people-centric slant has required a shift to a more consultative approach which, in return, promises a situation where individuals and communities are respected for and given opportunity to negotiate with the state on matters 
such as rules, regulations and processes directly related to them (Loh, 2008).

Indeed, civic participation is seen as a catalyst for defining new public-state relations, obtaining more effective distribution of benefits and for providing a potential remedy to problems of poverty and social inequity among the excluded and marginalized (Balooni \& Inoue, 2007; H. Zafarullah \& Huque, 2012; H. M. Zafarullah \& Huque, 2006). The effective implementation of such a significant shift in governance, particularly as it relates to advancement initiatives in developing Asian countries, is noted as being no easy feat, requiring changes not only in deep-rooted political structures and cultures (Reid, 2005), but also in societal cultures, local capacity and impetus, and in planning and intervention practices (Hussein, 1995).

Despite some good intentions and notable inroads, studies have shown that decentralized participatory initiatives in developing Asia are still very much embryonic (H. M. Zafarullah, 2004). Moreover, in many cases they have been found to exist merely as rhetoric, not involving nor benefiting those that really need it (Lavigne-Delville, Sellamna, \& Mathieu, 2005; Nagel et al., 2004).

However, by involving local people upon whom development initiatives will impact, civic participation is believed to be able to help appropriate valid and credible conditions in governance, foster greater collaboration between the state and communities, and achieve project effectiveness and efficiencies in labour and resourcing $(\mathrm{H}$. $\mathrm{M}$. Zafarullah, 2004). For the local people, their involvement in a democratically governed participatory development initiative can lead to increased self-esteem, dignity, confidence and empowerment. It can also assist in building their assets and capabilities, facilitate self-reliance and social interactions, as well as giving them opportunity to democratically influence initiatives impacting them (Sanjay Kumar, 2002; Midgley, 1986; H. M. Zafarullah \& Huque, 2006).

\section{Perspectives of participatory approaches}

Perceptions diverge, however, on what participation really means, who it involves and what it is expected to achieve (Agarwal, 2001)(S. Kumar, 2002)(Lane, 1995). The definition given to participation is broad and largely dependent upon the context and background in which it is applied. At its narrowest, participation is defined in terms of nominal membership and may include local people in things such as construction and implementation, but not in decision making (Agarwal, 2001)(S. Kumar, 2002)(Lane, 1995). In such instances, its objectives are measured on its efficiencies (Agarwal, 2001). At its broadest, participation is a dynamic interactive process that includes local people throughout the decision-making and execution process, measuring its success in terms of its ability to enhance wellbeing, efficiencies, equality, empowerment and sustainability (Agarwal, 2001)(S. Kumar, 2002)(Lane, 1995). In this, its truest form, participatory development is focused on the needs and interests of local people: "development of the people, for the people and by the people" (H. M. Zafarullah, 2004).

Many models exist outlining the various types of participatory approaches. In his World Bank Discussion Paper, Samuel Paul (1987) identifies four alternative approaches, each representing a different relationship between the 
funding agency and its local beneficiaries. Paul's approaches include: (i) information sharing where flows of information and control are in a downward direction from agency to beneficiary; (ii) consultation - where more equal information flows exist, however control is still held at the top; (iii) decision-making - where local benefactors have some command over the process; and (iv) initiating action - where both information and control flows are predominantly upward with a minimal degree of control retained by the funding agency. Others have conceived alternative models with as many as seven types of participatory approaches, including additional stages of extreme passivism, a stage where labour is given by locals in return for incentives such as food or money, and a stage of practical involvement in the latter stages of development only (Agarwal, 2001)(S. Kumar, 2002)(H. M. Zafarullah \& Huque, 2006). In all models cited, a form of self-mobilization typically sits at the 'ideal' end of the continuum, representing a more intense degree of participation, thus a greater likelihood of civic power and democracy (H. M. Zafarullah \& Huque, 2006).

\section{Paradoxes of participatory development}

Despite the acknowledged benefits of civic participation in local governance, especially in such areas as poverty alleviation, environmental protection, water resources management and health delivery systems, the extent to which participation has been incorporated into constitutional and statutory provisions differs between countries, as does the extent of its practice $(\mathrm{H}$. M. Zafarullah, 2004). In most decentralized participatory initiatives within developing Asia participation has been found to exist more in rhetoric than in practice (S. Kumar, 2002). Subsequently, the minimal application and/or effective leveraging of such governance paradigms have been found to have rendered little improvements concerning poverty and democratic rights of many disadvantaged people living within impacted areas of developing Asia (Agarwal, 2001).

The key paradoxes which exist in participatory approaches are largely the result of inherent conflicts around the devolution of power and the state's objectives for 'empowering' the local people in the first place (Hussein, 1995; H. M. Zafarullah, 2004). Some suggest distinct differences exist depending on whether participation is seen by the state as a means for improving project effectiveness or whether participation is seen as an 'end' in its own right. The latter referring to a focus on intrinsic benefits of participation, such as increasing confidence, self-esteem and the local community's sense of empowerment (Lane, 1995). Extent of participation is also very much influenced by the state's political structure and approach to decentralization.

Despite their expressed intent to devolve powers and encourage civic participation, many countries in developing Asia still have their governments maintaining a hegemonic position through the centralized bureaucracy, often due to their desire to control what are often scarce resources, as well as their dependence on external aid and the need to coordinate relationships with both funding bodies and local people (Lavigne-Delville et al., 2005). Thailand is one such example where, despite constituting policies for decentralization in the 1990s, administrative power is still heavily 
concentrated in central agencies $(\mathrm{H}$. M. Zafarullah, 2004). Similarly, in Indonesia the local government has progressed to some extent with the introduction of a hybrid model combining decentralization, deconcentration, and 'coadministration' principles. Yet, in practice local-level planning remains a bureaucratized activity inhibiting the development of local democracy and the ability of people at the grassroots to have any influence over planning (H. M. Zafarullah, 2004).

Even in instances where decentralization and local participation has been attempted in communities, it has become evident that there are limits to what can be achieved given the preexisting socioeconomic inequalities, power relations and conflicting interests that exist within local communities (Agarwal, 2001; Nagel et al., 2004). Although not always immediately evident to an outsider's eye, all communities have their own dynamics and divisions according to gender, status, income, ambitions, political affiliations etc. There can also be land right issues and hierarchical relationships which often trace back generations. Some argue that representation of the people is often selective, and often favored toward the community elites, failing to take into account the interests and aspirations of the whole community (Midgley, 1986). In such instances, the risk of resources being manipulated or squandered by powerful community elites is not uncommon (H. M. Zafarullah, 2004), nor is the exclusion of many of the community minority groups, such as women and 'outsiders' who are often among the most disadvantaged (Agarwal, 2001; Midgley, 1986). Examples from Indian and Nepalese forestry programs have shown that whilst successes may exist in terms of halting forest degradation or in advancing already advanced community members, some disadvantaged locals have been found to be worse off than they were before development began, with their resources depleted and no avenue for compensation. Moreover, forecasts for their livelihood in the long term are claimed to also look bleak (Agarwal, 2001; Sanjay Kumar, 2002; Nagel et al., 2004), particularly when interpretations of the concept are still so varied and somewhat ambiguous.

\section{Decentralized Democratic Participation in Bangladesh:}

Creating a policy space where stakeholders from all sections of society can participate has been one of the greatest challenges in the development discourse of Bangladesh. The policy makers of the country have increasingly acknowledged the fact that development policies have differential impact on different classes of people and this asymmetrical impact is occurring due to omitting the needs of some people from the policy focus which again shows differences in levels of participation and extent of representation in the policy cycle. However, for a useful, reactive and equity ensuring development, it is important to increase ownership through making proactive and participatory citizens.

In Bangladesh, there are varying reasons for turning to decentralization. The act of decentralization, although started as an engine of fighting against administrative and fiscal irregularities and improving the delivery of basic services, implicitly served the interests of political motives. As a result, the representatives of local administration are not given the sole 
responsibility of controlling and monitoring the basic missions of undertaking decentralization.

Decentralized participatory development is a crucial element for enhancing the quality of governance. Bangladesh, now with a satisfactory outgrowth in the economy and a resilient impact on achieving targets of Millennium Development Goals (MDGs), is still struggling to achieve a favourable condition in equity and social justice. Policies to reduce poverty are failing to minimize income inequality, and as a result, the difference between the rich and the poor is still rising. A break down in social security calls for more dynamism in strategies for rural development, women empowerment and human resource development. Generating participation of a broader section of citizens in policies which are formulated for them can only act to combat criticism and raise appreciation for exhibiting tangible positive changes in the socioeconomic sphere. Maintenance of macroeconomic stability, social protection, curbing corruption, control over market and price hike, adequacy in power and energy generation and eliminating poverty and inequality root for systemic inclusion and will of civil society, chairman and members of local governments, political activists, religious leaders, private and international agencies along with common people.

\section{Toward effective decentralization}

For a decentralized participatory governance framework to truly succeed devolution of State power and the voluntary and ongoing inclusion of those most impacted by the proposed development must exist (Abbass, 2004). Additionally, priority must be given to empowering and building the skill and resource capacity of local communities to ensure they can effectively manage and sustain their own natural resources (Abbass, 2004; Balooni \& Inoue, 2007; Guess, 2005; Hussein, 1995). Indeed, evaluations have shown that often problems lie in wellintentioned devolution plans not providing enough support to the community in the way of technical skills, thus creating problems for implementation and long term sustainability (Guess, 2005).

Other critical success factors include the building up of a cooperative spirit among locals and the minimal use of outside intervention. While some initial stimulation may be needed to encourage and raise the 'consciousness' of local people to get them to participate truly, local people must be free to develop their own thoughts and ideas without too much intervention (Hussein, 1995). Additionally, recognition, respect for, and the appropriate use of indigenous knowledge and practice are also paramount, not only in benefiting the local people but also in providing a level of local intelligence not easily sourced elsewhere (Guess, 2005). In line with this is the need to understand the social and cultural constraints impacting various community members. Deep-rooted changes in political power structures are also an inevitable requirement of achieving industry transformation and positive impacts on poverty (Reid, 2005). Not least, is the need for appropriate intent on behalf of the state in relation to their objectives for engaging participatory development in the first place $(\mathrm{H}$. M. Zafarullah, 2004).

Despite shortcomings in many development projects across developing Asia, some countries do show signs of modest success. The Philippines is one nation which many 
believe has implemented one of the most successful and far-reaching decentralized participatory governance structures in the region (Guess, 2005; Reid, 2005; H. M. Zafarullah, 2004). Starting in the late 1980's, the Philippines shifted toward a concept of local civic participation and autonomy, authenticated in their 1987 Constitution and later in their Local Government Code of 1991 (Guess, 2005; Reid, 2005). The change in governance is noted as having fostered "creativity, imagination and innovation at the local level, and positive signs of accomplishment in local autonomy" (H. M. Zafarullah, 2004). The nexus between local people, NGOs and local government have also been claimed as having "created opportunities for participation in facilitating community decision making, undertaking communication projects, managing sustainable development programs, facilitating the delivery of health services, establishing 'comprehensive' cooperative development programs, promoting advocacy for better governmental performance and conducting systematic monitoring and evaluation". Similar examples of success, albeit on a lesser scale, have been seen in Malaysia's Sustainable Penang Initiative (SPI) and the Palli Karma Sahayak Foundation (PKSF) in Bangladesh (Paul, 1987)(H. M. Zafarullah, 2004). The World Bank has recognized both initiatives as "autonomous, community-driven development programs which are operating with political, administrative and financial flexibility and with a fair degree of transparency" (Paul, 1987). Additionally, their democratic decentralized governance structure has been attributed to the fostering of effective, collaborative relations between locals, government and partnering NGOs, resulting in positive implications for participatory development (H. M. Zafarullah, 2004).

\section{Conclusion}

There is no denying the theoretical and intuitive argument that participatory development and decentralized governance, in their symbiotic existence, provide an effective tool for reducing poverty and increasing social rights among local people. To date however, there appears little evidence of this being conclusively and extensively proven in practice. Despite the many benefits associated with the ideology, both for the state and for the well-being and sustainability of local people and resources, current participatory methods being used and the extent to which they are being applied would appear to be a major contributing factor to the lack of witnessed success. Indeed, 'real' democratic decentralized civic participation practices still appear to be embryonic in their developmental stage within societal, economic and political structures of developing Asia. Whether this is due to a reluctance to relinquish power or other contributing factors is unclear. What is clear is that so long as the States remain largely resistant to civic participation in its 'true' form of genuine local decision making and empowerment, the 'application' of participatory practice is likely to continue to serve merely as idealized rhetoric or as an interim band-aid solution to a much bigger and long lasting issue of marginalization and disempowerment . Moreover, and perhaps more importantly, the state's less than adequate attempts of implementation and inclusion, will continue to risk disenfranchising and even disadvantaging already disadvantaged and marginalized members of local community. 


\section{Acknowledgments}

The author would like to thank Department of Public Administration, Faculty of Social Science, Bangabandhu Sheikh Mujibur Rahman Science and Technology University of Bangladesh, for their supports to do this research article.

\section{References}

Abbass,

D. (2004).

Decentralisation in forestry continues despite disappointments. Appropriate Technology, 31(3), 32.

Agarwal,

B. (2001).

Participatory exclusions, community forestry, and gender: An analysis for South Asia and a conceptual framework. World Development, 29(10), 1623-1648.

Balooni, K., \& Inoue, M. (2007). Decentralized forest management in South and Southeast Asia. Journal of Forestry, 105(8), 414-420.

Chambers,

R. (2013).

Participation for development: A good time to be alive. Development Bulletin, 75, 4-9.

Guess, G. M. (2005). Comparative decentralization lessons from Pakistan, Indonesia, and the Philippines. Public Administration Review, 65(2), 217-230.

Hussein, K.

Participatory ideology and practical development: agency control in a fisheries project, Kariba lake. In Power and Participatory Development. Theory and Practice. London: Intermediate Technology Publications.

Keough, N. (1998).

Participatory development principles and practice: Reflections of a western development worker. Community Development Journal, 33(3), 187-196.

Kumar, S. (2002). Does "participation" in common pool resource management help the poor? A social cost-benefit analysis of joint forest management in Jharkhand,
India. World Development, 30(5), 763-782.

Kumar, S. (2002). Methods for Community Participation: A Complete Guide for Practitioners. London: ITDG Publishing.

$$
\text { Lane, J. (1995). Non- }
$$
governmental organizations and participatory development: the concept in theory versus the concept in practice. In Power and Participatory Development: Theory and Practice. London: Intermediate Technology Publications.

Lavigne-Delville, P., Sellamna, N.-E., \& Mathieu, M. (2005). Living up to ambitions: For a more rigorous practice of participatory appraisals and inquiries. In A. Neef (Ed.), Participatory Development: Theory and Practice (pp. 170-180). London: Intermediate Technology Publications.

Loh, F. K. W. (2008). Procedural democracy, participatory democracy and regional networking: the multi-terrain struggle for democracy in Southeast Asia. InterAsia Cultural Studies, 9(1), 127-141.

Midgley, J. (1986). Community Participation, Social Development and the State. New York: Methuen \& Co.

Mohan,

G. (2007) Participatory development: from epistemological reversals to active citizenship. Geography Compass, 1(4), 779-796.

Muñoz, L. G. C., Acosta, A. J. O., \& Moreno, L. D. (2006). Aspectos ba' sicos de la descentralización en México. Mexico City: Instituto Nacional para el Federalismo y el Desarrollo Municipal.

Nagel, U., Heidhues, F., Horne, P., \& Neef, A. (2004). Participatory approaches for sustainable land use in Southeast Asia: Lessons learned and challenges remaining. In A. Neef (Ed.), Participatory Approaches for Sustainable Land Use in Southeast Asia 
(pp. 359-370). Bangkok: White Lotus Press.

Parfitt, T. (2004). The ambiguity of participation: a qualified defence of participatory development. Third World Quarterly, 25(3), 537-555.

Paul, S. (1987). Community participation in development projects. Washington, DC: World Bank.

Reid, B. (2005). Poverty alleviation and participatory development in the Philippines. Journal of Contemporary Asia, 35(1), 29-52.

Rondinelli, D. A., \& Nellis, J. R. (1986). Assessing decentralization policies in developing countries: The case for cautious optimism 1 . Development Policy Review, 4(1), 323.

Rondinelli, D. A., Nellis, J. R., \& Cheema, G. S. (1983). Decentralization in developing countries. In World Bank staff working paper (Vol. 581).

Thomas,

P.

(2013).

Introduction: Challenges for participatory development in contemporary development practice. Development Bulletin, 75.

Zafarullah, H., \& Huque, A. S. (2012). Managing development in a globalized world: Concepts, processes, institutions. Florida: CRC Press.

Zafarullah, H. M. (2004). Decentralized governance and participatory development: The asian experience. In Handbook of development policy studies. Boca Raton: CRC/Taylor \& Francis.

Zafarullah, H. M., \& Huque, A. S. (2006). Understanding development governance: concepts, institutions, and processes. In International development governance. CRC Press.

(C) 2020 by Author. Submitted for possible open access publication under the terms and conditions of the Creative Commons Attribution (CC-BY-SA) license (https://creativecommons.org/licenses/by-sa/3.0/). 